\title{
STUDIES ON THE PHYSICAL ANTHROPOLOGY OF THE NETHERLANDS ANTILLES: IV
}

\author{
A PRAE-COLUMBIAN SKELETON FROM BONAIRE
}

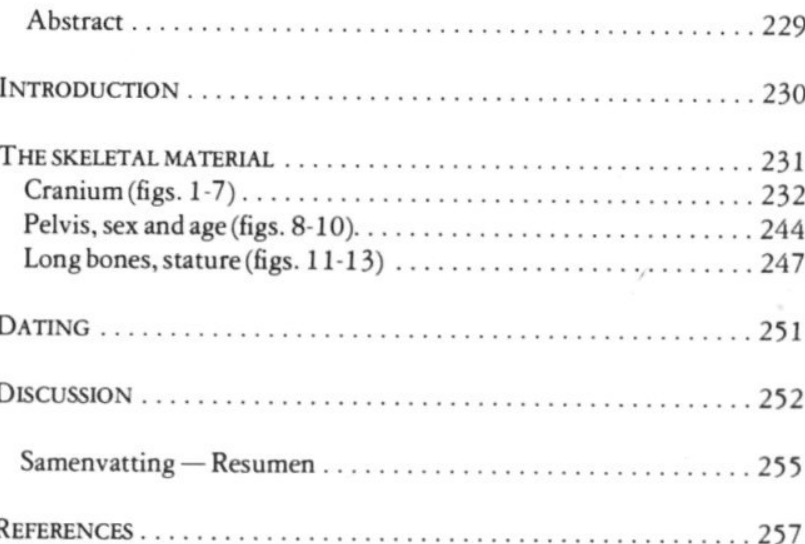

\section{ABSTRACT}

The skeleton from Bonaire was found accidentally during building activities; these could be stopped long enough to collect the fragments of the skull and the post-cranial skeleton. These were sent to the author and after reconstruction proved eventually to form - however damaged - the most complete skeleton from the Lesser Antilles submitted to the author for a study.

Dating $\left(\mathrm{C}^{14}\right)$ put the skeleton at an age of 760 years \pm 25 years B.P. a fact which a.o. confirmed the racial diagnosis of the skeleton as 'American Indian'. The sex was male and the individual must have reached an age of $40-50$ years as testified by characteristics of the skull and of the pelvic fragments. 
The skull proved to be hyperbrachycraneous (cranial index 86.55); high with regard to the length (height/length index 74.85) and low with regard to the breadth (height/breadth index 86.49). The upper facial index of 54.60 indicates that the facial skeleton is of medium width; the orbits are high (orbital index 85.71); the nose is rather narrow (nasal index 46.15). Evident signs of artificial cranial deformation are absent.

From the intact right radius and ulna the body length could be computed; the outcome around $175 \mathrm{~cm}$ - looked surprisingly high if compared with present data of the living Indians on the nearby continent; not so however if historical accounts are taken into consideration.

In comparison with data gathered in the past from Venezuelan Indian groups and from the living it may be concluded that the Bonaire skeleton was slightly more brachycraneous, had a narrower nose and a slightly broader facial skeleton. The stature distinctly exceeds data based on the living in the north-western part of the South-American continent.

\section{INTRODUCTION}

Skeletal material from the Dutch Antilles, which is in such a reasonable state of preservation that either the skull or the skull and parts of the post-cranial skeleton can be submitted to a study is rare. Studies on Amerindian skeletal finds from this region are listed below in a chronological sequence:

KOEZE (1904): 4 skulls from Aruba and 1 skull from Curaçao. TACOMA (1959, 1964 and 1965): 12 skulls from Aruba (of which 1 was already mentioned by KOEZE) and 1 skull from Curaçao; the latter originated from a discovery by RINGMA of skeletal remains of 6 individuals - see WAGENAAR HUMMELINCK (1959).

ENGELS (1970): 1 complete skeleton with a postmortal deformation of the skull.

The skulls mentioned are mostly medium-sized and most proved to be meso- to brachycraneous, high in comparison to the length and of medium height or low in comparison to the breadth. Sequelae of artificial (plano-frontal) cranial deformation were found in some of the specimens. The above studies do not mention stature with the exception of the publication of ENGELS wo discussed the subject extensively.

At the end of 1976 the local Antillen news-paper made mention of a skeletal find discovered during operations necessary for the building of a MAVO-school in Kralendijk on the isle of Bonaire. The building-activites could be stopped long enough to collect the skeleton as well as circumstances permitted; thereafter it was kept 
in the custody of drs. E. AYUBI, head of the archaeological service of the Netherlands Antilles. Eventually, with the cooperation of drs. AYUBI and the formal permission of the 'Gezaghebber' of Bonaire, the skeleton was sent to the Anatomical Institute of the State University of Utrecht to be studied by the author. Much gratitude has to be expressed to drs. L.H. DAAL (office of the plenipotentiary minister in the Netherlands) who did all he could to promote this study and who greatly facilitated the contacts between the author and the local Antillean authorities; to dr. P. WAGENAAR HUMMELINCK and drs. L.J. VAN DER STEEN whose encouragement paved the way to a continuation of the series 'Studies on the Physical Anthropology of the Netherlands Antilles' which did start once in De West-Indische Gids; to mr. J. KEMPERMAN who not only took great pains to promote the expedition of this skeleton to the Netherlands but also reconstructed the skeletal parts from the fragments which were its remains. Mr. KEMPERMAN also expertly preserved the several resulting components of the skeleton by impregnation with polyvinylchloride ('Archaeoderm' Filoform).

\section{The Skeletal Material}

From the fragments the skeletal components were reconstructed as well as possible; fragments and even whole bones proved to be missing but keeping in mind the skeletal remains which could be studied in the past, it can be stated without hesitation that the skeleton under discussion was by far the best preserved, the most complete and, last but not least, the most carefully treated find.

It proved to consist of:

- A nearly complete skull and lower jaw.

- More than half the amount of vertebrae, i.e. the axis and 4 cervical vertebrae, 11 thoracic vertebrae and fragments of the lumbar spine. Unfortunately the atlas was absent; it presence could have added information about the sex of the individual.

- The pelvis was represented by a heavily damaged os sacrum, the posterior half of the left and right os coxae and the corpus and upper ramus of the left os pubis. 
- Fragments of the shoulder girdle and of the thoracic cage were present; so were the long bones of the arm and leg though most were heavily damaged at their epiphyseal ends; the left radius was missing.

It was ascertained very carefully that no fragments of a second skeleton were among the remains studied.

In the following are presented successively a description of the skull and the mandible together with their measurements and indices, a description of the pelvic remains with a discussion on the sex and age of the individual and the measurements and indices of the long bones and the stature derived from these data.

\section{CRANIUM (fig. 1-7)}

The speciment has a light brown color with lighter and darker spots; erosion is present in some places. Rather extensive damage is present in the region of the left coronary suture and the left pterion; the malar arch is absent on this side. This applies also - the extent of damage being slightly less - to the right side. Damaged also are the medial walls of the orbits. Damage of the base of the skull was not so extensive that a reconstruction of basion was impossible. In comparison with the earlier described finds from the Antilles the condition of this skull merits all praise.

The sex of the skull was thought to be male in view of the rather strong development of the areas of muscular insertion, the development of the tuber frontale and parietale relative to each other and the configuration of the upper rim of the orbit. The sexing of the skeleton as male was made not only on the base of the skull but also with a view to the characteristics of the post-cranial skeleton especially those of the dorsal parts of the innominate bone.

The age at death was estimated with the help of the pattern of closure of the cranial sutures as well as with the characteristics of the surface of the symphysis pubis. Traces of the sagittal suture are still visible, lambda shows up as a meeting-place of three thin undulating lines; ossification started in the middle of the sagittal suture. The ossification of the coronary suture slightly lags behind that of the sagittal suture. On the base of this closure-pattern it can 


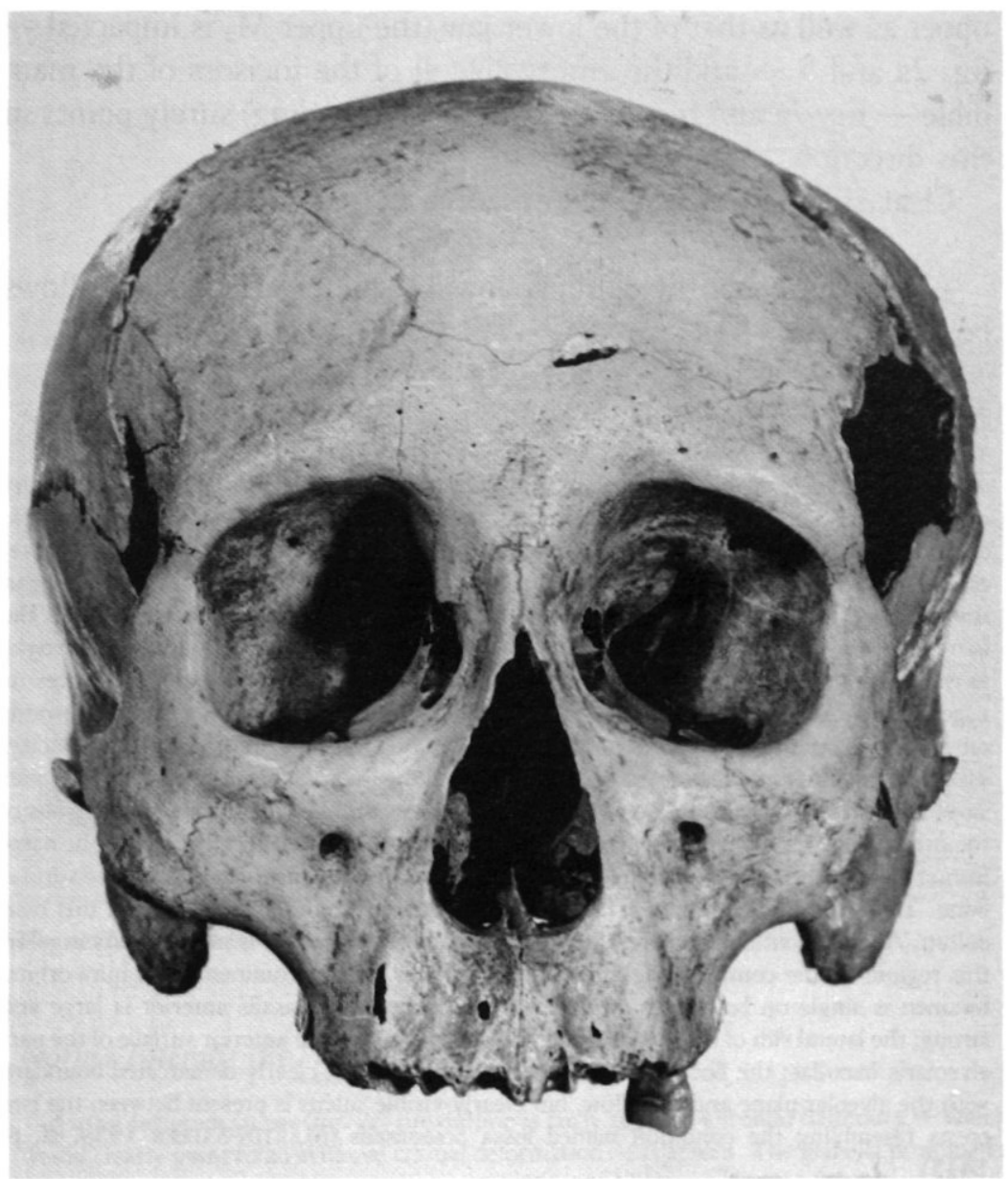

Figure 1: Norma frontalis.

be stated that the individual must have been middle-aged at death, probably exceeding the age of 40 years; an assessment which proved to be corroborated by the configuration of the symphyseal surface.

The question has to be answered if the individual was amerindian. The high, rather round orbits, the flatness and prominence of the infra-orbital region, the smallness of the alveolar part of the 
upper as well as that of the lower jaw (the upper $\mathrm{M}_{3}$ is impacted fig. $2 \mathrm{a}$ and 5 - and the empty alveoli of the incisors of the mandible - fig. 7a and $b-$ are a witness of crowding) surely points in this direction.

Clear signs of artificial deformation were absent.

A description of the skull, following the usual normae, follows below.

Norma Frontalis (fig. 1; table 1)

Apart from the damage mentioned before, the squama frontalis forms a regular convexity on which slight traces of the tubera frontalia can be felt rather than seen. The metopic suture is synostosed and shows its usual remains above the nasion. The left and right supraorbital arcs form broad, distinct elevations above the medial half of the orbit; they merge in the midline to forms a slightly prominating glabella which slopes downwards towards the barely receding nasion. The supra-orbital rims are broad and strong and present on the right as well as on the left side a shallow, barely demarcated incisura supra-orbitalis; the processus zygomaticus ossis frontalis, equally strong as the rest of the orbital rim, slopes downwards on its way to the frontal process of the malar bone. The high orbits tend to rotundity, especially by the roundness of the infero-medial and the infero-lateral angle; their long axes slope from medio-superior to latero-inferior. As was mentioned before, the medial walls of the orbits were heavily damaged; the point 'naso-frontale' was left luckily intact. The nasofrontal suture presents in the midline an irregularity, probably due to an intercalated sutural bone. The referencepoint 'nasion' was placed arbitrarily at the lower border of this ossiculum. As was mentioned before, the fossa canina is flat and there is no concavity at all in this region; on the contrary, the infra-orbital region is rather prominent. The infra-orbital foramen is single on both sides and rather large. The spina nasalis anterior is large and strong; the lateral rim of the piriform aperture fades away on the anterior surface of the pars alveolaris maxillae; the floor of the nasal cavity has its own, clearly demarcated boundary with the alveolar plane and a shallow, but clearly visible sulcus is present between the two crests resembling the condition named fossa praenasalis (MARTIN-SALLER 1959, II, p. 1415).

TABLE 1: Measurements and indices pertaining to the norma frontalis.

$\begin{array}{ll}\text { M. } 45 \text { - bimalar breadth } & 141 \\ \text { M.48 - upper facial height } & 77 \\ \text { M. } 51 \text { - orbital breadth } & 42 \\ \text { M. } 52 \text { - orbital height } & 36 \\ \text { M. } 54 \text { - nasal breadth } & 24 \\ \text { M. } 55 \text { - nasal height } & 52 \\ \text { I.39 - upper facial index } & 54.61 \\ \text { I.42 - orbital index } & 85.71 \\ \text { I.48 - nasal index } & 46.15\end{array}$




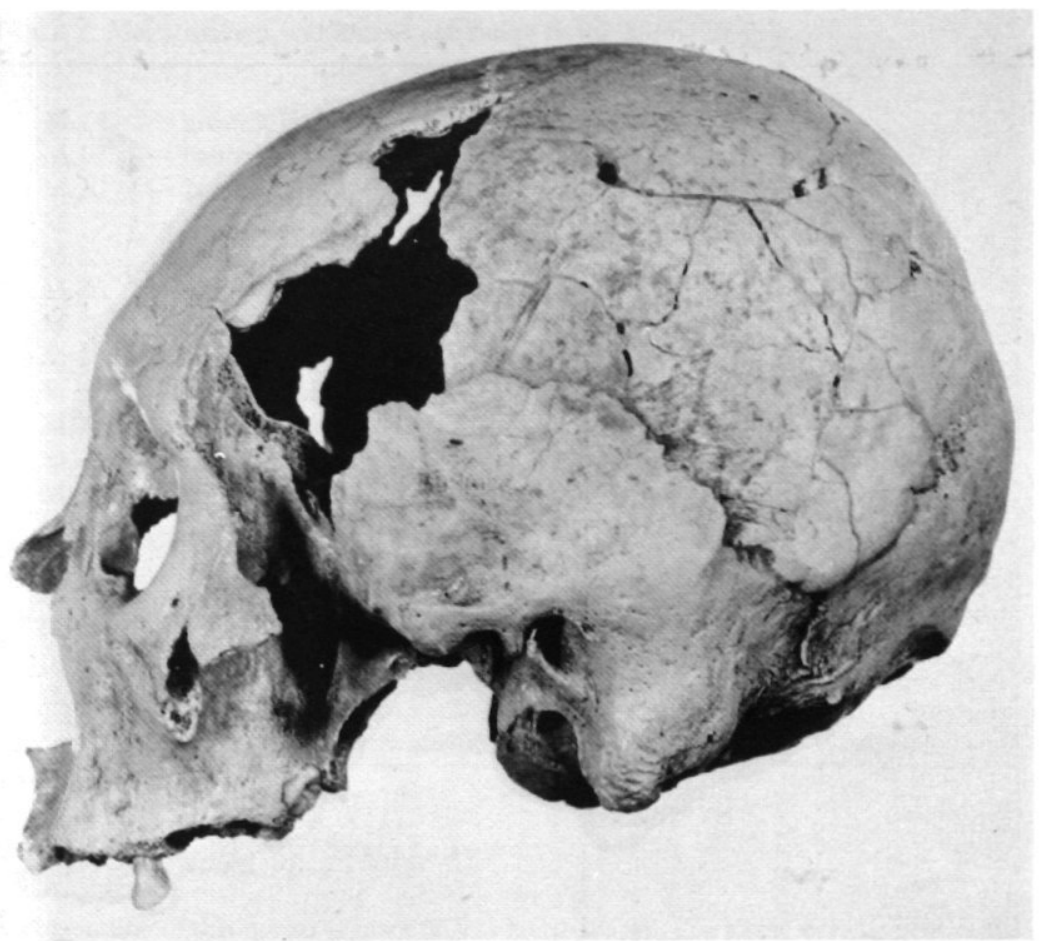

Figure 2a: Norma lateralis, left side.

Norma Lateralis (fig. 2a. b; table 2)

As the perigram shows (fig. 2c) the outline is fairly regular, a frontal flattening - which would clearly point to an artificial cranial deformation - is absent. The glabella prominates slightly and its convexity merges downwards into the slight concavity of the nasal bridge; the nasion lacks any special demarcation. The sagittal contour shows a barely perceptible obelic flattening; the protuberantia occipitalis externa does not prominate unduly but is rather flat and strongly built. In fig. $2 \mathrm{a}$ and $\mathrm{b}$ which depict the left and right side of the skull, the prominence of the anterior nasal spine can be seen clearly; the same applies to the damage of the malar arch and the pteric region. The dorsal rim of the processus frontalis ossis zygomaticus prominates slightly backwards, forming thus a processus marginalis of Soemmeringh. The upper rim of the (remaining) arcus zygomaticus extends towards above the meatus accusticus externus to form a clearly developed crista supramastoidea which forms a sharp upward bend and on its way upward can be followed unto the squamous suture; the dorsal side of this upper part forms part of this suture. As can be judged on the right - least damaged - side, the pterion in all probability had the form of an $\mathrm{H}$. The linea temporalis can be followed as a clear, rough line till it reaches the coronary suture; as it crosses the suture it angulates slightly upwards and on the parietal bone it quickly loses its conspiciousness. 


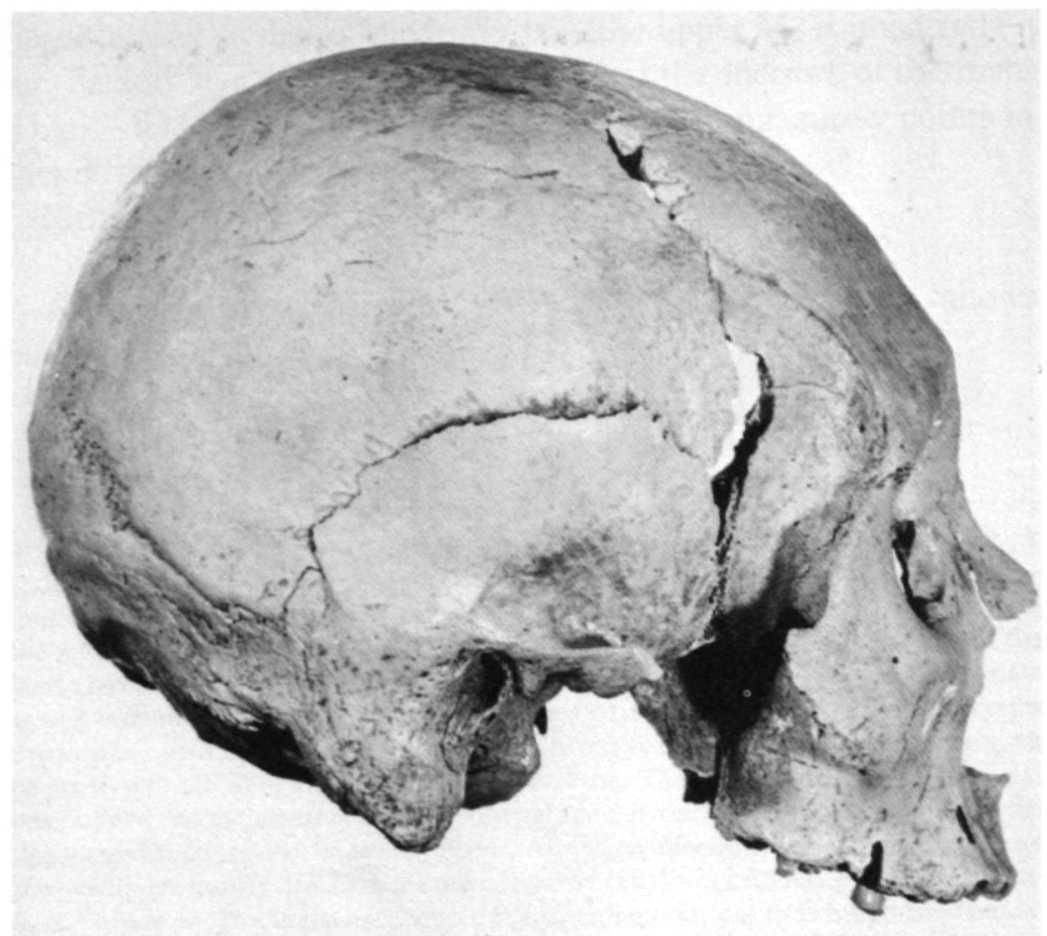

Figure 2b: Norma lateralis, right side.

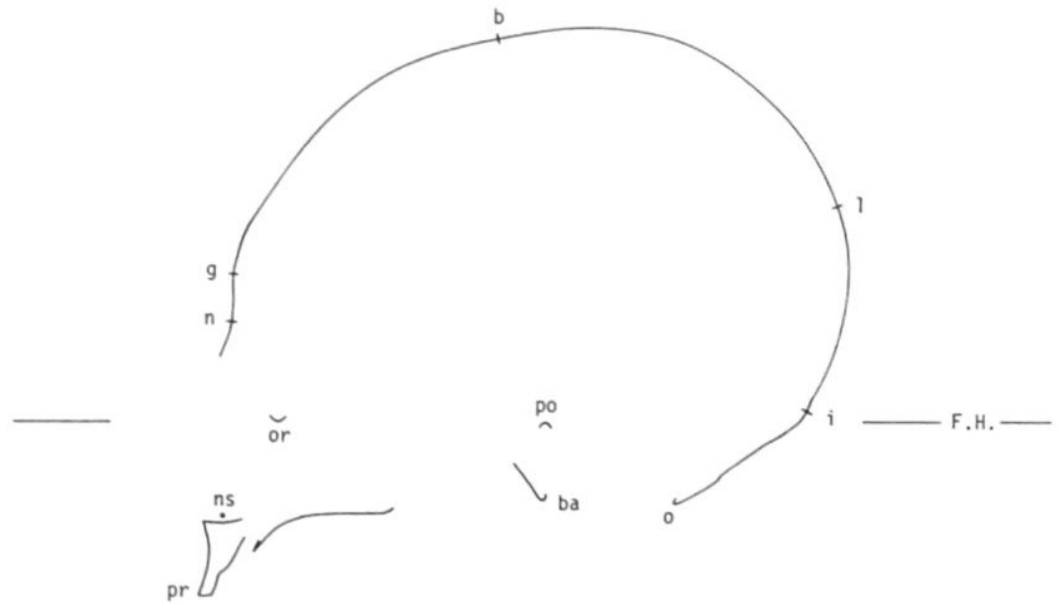

Figure 2c: Median outline tracing (perigram). 
TABLE 2: Measurements and indices pertaining to the norma lateralis.

$\begin{array}{llc}\text { M. } 1 & \text { - greatest length } & 171 \\ \text { M.17 } & \text { - basion bregma height } & 128 \\ \text { M.20 } & \text { - auriculobregm. height } & 104 \\ \text { M. } 5 & \text { - nasion-basion } & 98 \\ \text { M.25 } & \text { - sagittal arc } & 339 \\ \text { M.26 } & \text { - sag. frontal arc } & 119 \\ \text { M.29 } & \text { - sag. frontal chord } & 108 \\ \text { M.27 } & \text { - sag. parietal arc } & 113 \\ \text { M.30 } & \text { - sag. parietal chord } & 102 \\ \text { M.28 } & \text { - sag. occipital arc } & 107 \\ \text { M.31 } & \text { - sag. occipital chord } & 93 \\ \text { M.32(2) - bregma-glab.inion angle } & 57^{\circ} \\ \text { M.72 } & \text { - total facial angle } & 83.5^{\circ} \\ \text { M.40 } & \text { - prosthion-basion } & 97 \\ \text { I. } 2 & \text { - height/length index } & 74.85 \\ \text { I. } 4 & \text { - aur.bregm.height/length index } & 60.82 \\ \text { I.22 } & \text { - sag. frontal index } & 90.76 \\ \text { I.24 } & \text { - sag. parietal index } & 90.27 \\ \text { I.25 } & \text { - sag. occipital index } & 86.92\end{array}$

Norma Occipitalis (fig. 3; table 3)

The outline of this norma is more or less house-shaped, due to the development of the tubera parietalia. The vertical part of the circumference shows the prominating outline of the crista supra-mastoidea with the shallow sulcus below it; the region of the squamous suture forms a slight convexity outwards; the tubera partietalia do not prominate unduly, they form a rounded transition of this vertical part to the 'roof' of the circumference. The sagittal suture lies between slightly elevated longitudinal ridges. The advanced synostosis of lambda and its constituent sutures has been mentioned above; in the middle part of the lambdoid suture the serration is strong; its lower third prominates due to a strong development of its parietal component. The linea nuchalis superior stands out clearly and the bony spiculi at its lateral part are evidence of the strength of the muscles who had their insertion there. Also clearly developed is the linea nuchalis suprema. The area between the two lines forms a slightly elevated torus occipitalis. The area below the linea nuchalis superior is irregular, several crests bear evidence of the attachments of muscles; the linea nuchalis inferior is difficult to discern. The protuberantia occipitalis exerna is slightly more than the junction of the left and right linea nuchalis superior; it barely has an own prominence. The crista occipitalis externa on the contrary stands out as a clearly defined sharp ridge.

TABLE 3: Measurements and indices pertaining to the norma occipitalis.
M. 8- greatest breadth
148
M.12 - asterion breadth $\quad 117$
I. 3 - height/breadth index $\quad 86.49$
- ast. breadth/greatest breadth 79.05 


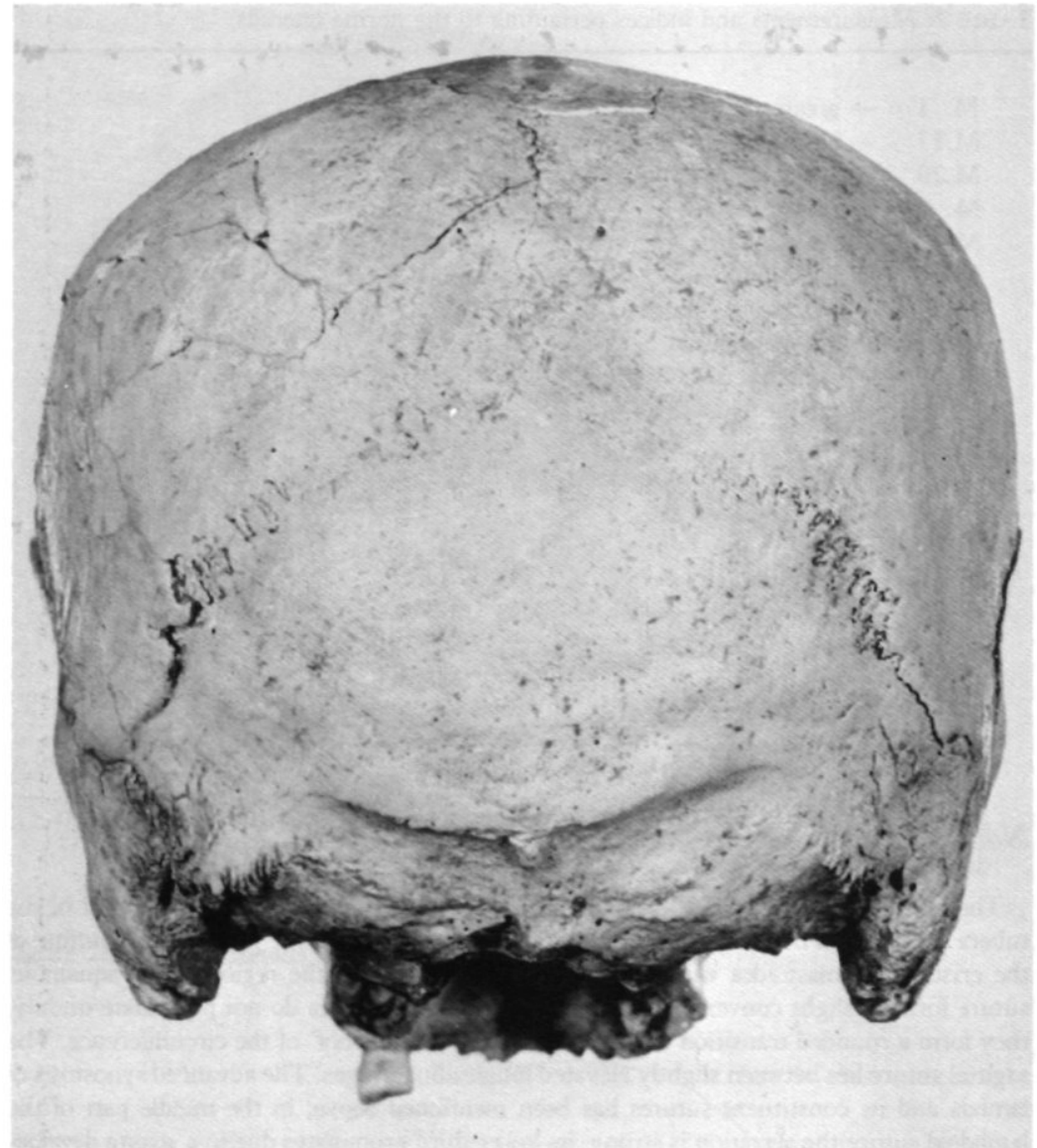

Figure 3: Norma occipitalis.

Norma Verticalis (fig. 4; table 4)

There is an absence of conspicuous irregularities in the horizontal outline (apart from the damaged areas mentioned before). The rounded anterior part of the outline is followed backwards by the constricted area of the fossa temporalis; on the anterior part of this outline the prominence of the left and right arcus supra-orbitalis is visible. The skull is slightly asym- 


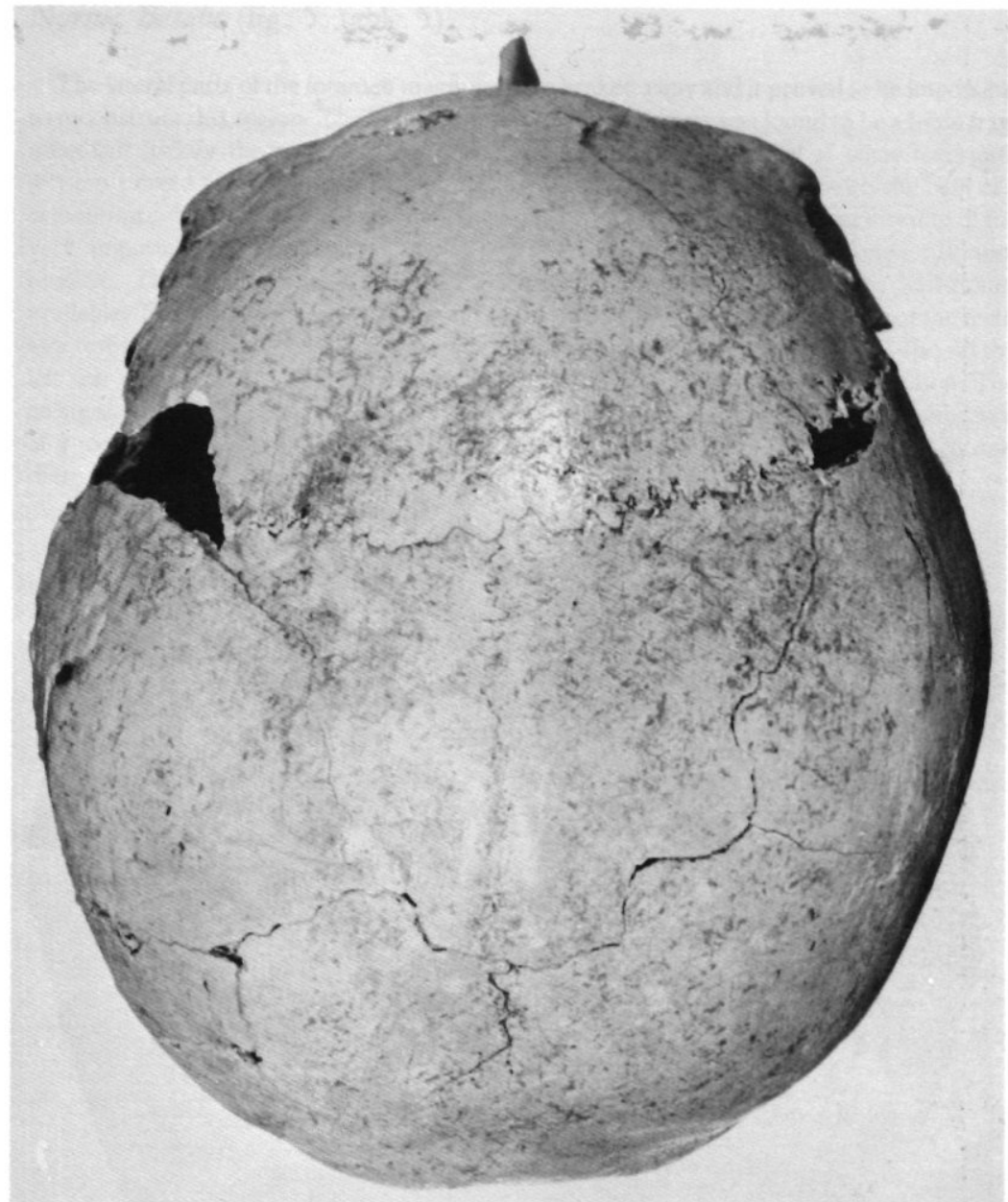

Figure 4: Norma verticalis.

metrical and the malar arches are clearly visible from above. The pattern of synostosis of the sutures has been described above; there is a very small parietal foramen on the right side of obelion. The very slight degree of obelic flattening has been described above. Sutural bones are absent; the slight elevation in which the sagittal suture forms its shallow sulcus has been mentioned before. 


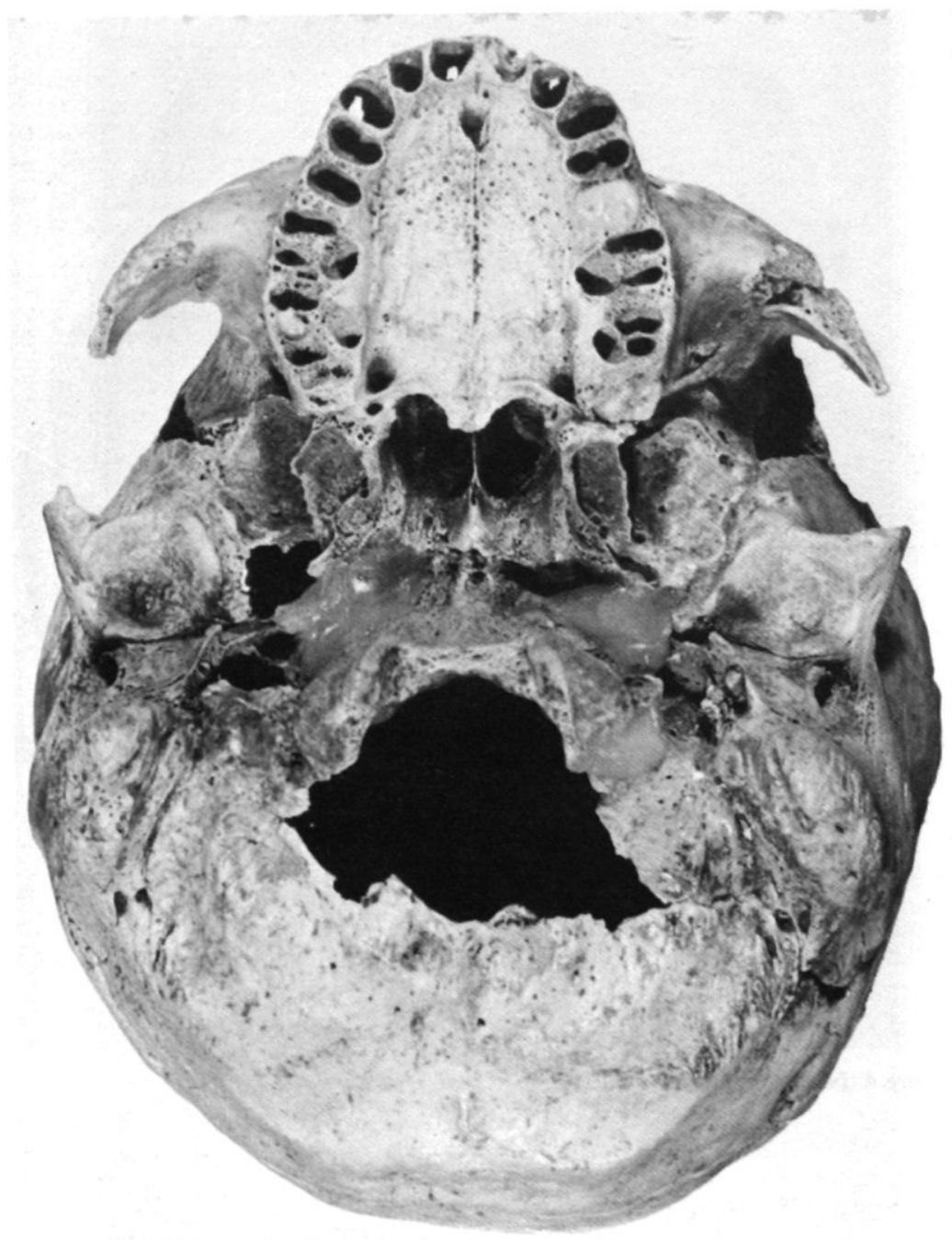

Figure 5: Norma basalis; note the impacted $\mathrm{M}_{3}$ left. 


\section{Norma Basalis (fig. 5; table 5)}

The lateral parts of the foramen magnum were broken away and it proved to be impossible to reconstruct this region. The basilar part of the occipital bone was found to be a loose fragment but luckily the exact location of the piece could be ascertained as some bony projections proved to have fitting counterparts in the rest of the skull-base. With the help of a cementing substance it could be fitted in its proper place which made an exact location of the very important reference-point 'basion' on the anterior rim of the foramen magnum possible. The damaged dorsal rim of the foramen magnum fortunately kept 'opisthion' available. The paraboloid alveolar part of the maxilla presents the empty sockets of the teeth as a testimony of their postmortal loss; the only teeth present are the left $\mathrm{P}_{2}$ and also on the left side an impacted $\mathrm{M}_{3}$; the alveoli on the right side do not show a similar impaction. The palate shows its usual ridges which in this specimen are rather outspoken. There is no trace of a torus palatinus. The left and right foramen palatinum majus are large; on each side there is but one foramen palatinum minus.

TABLE 4: Measurements and indices pertaining to the norma verticalis.
M. 1 - greatest length
171
M. 8 - greatest breadth
148
M. 9 - frontal breadth ( $\mathrm{min}$.
M. 10 - frontal breadth (max.)
119
M.12 - asterion breadth
117
I. 1 - cranial index
86.55
I.12 - transverse frontal index
80.67
- ast.breadth/greatest breadth
79.05
I.13 - transv. fronto/par. index
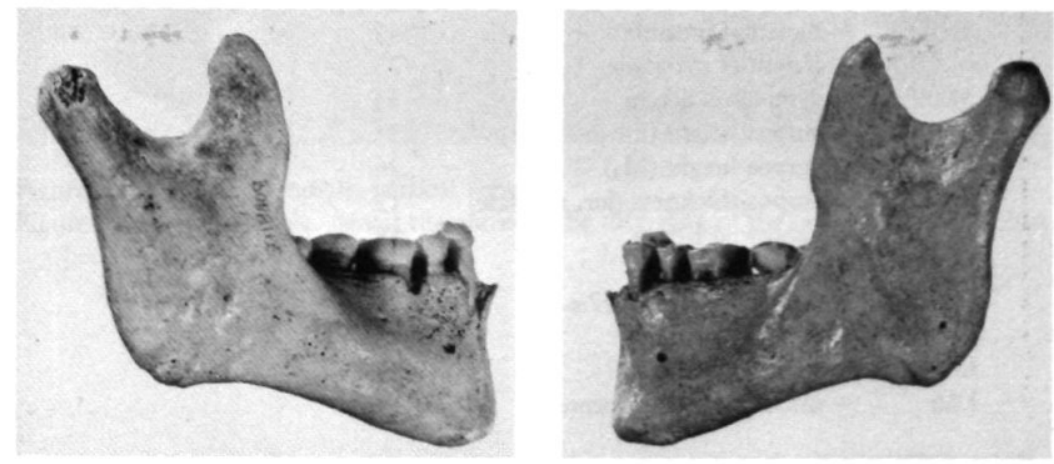

Figure $6 \mathrm{a} / \mathrm{b}$. Mandible, lateral view. 
TABLE 5: Measurements and indices pertaining to the norma basalis.

$\begin{array}{ll}\text { M. } 7 \text { - for. magnum length } & 38 \\ \text { M.16 - for. magnum breadth } & - \\ \text { M.40 - prosthion-basion } & 97 \\ \text { M.62 - palate length } & 49 \\ \text { M.63 - palate breadth } & 34 \\ \text { M.64 - palate height } & - \\ \text { I.33 - palatal index } & 65.31\end{array}$

The Mandible (fig. 6-7; table 6)

The mandible is very well preserved; the lateral part of the right capitulum showed damage of the corticalis and there was a postmortal loss of teeth (on the left the $\mathrm{M}_{3}-\mathrm{M}_{2}-\mathrm{C}-\mathrm{I}_{2}$ and $I_{1}$ and on the right side the $I_{2}$ and $I_{1}$ ). The right $M_{2}$ is damaged and dental abrasion is quite marked with the exception of the $\mathrm{M}_{3}$ on the right side. The alveoli of the central incisors (fig. 7b) point to crowding of the teeth in this area.

The mandible itself is robust, it has a well-developed angulus and processus coronoideus; the anterior rim of latter forms a distinct projection in the anterior direction. Below the articular surface of the processus condylaris the fovea pterygoidea forms a shallow depression. These characteristics, together with the crests on the inner and the outer side of the angulus point to the strength of the muscles of mastication; a testimony of this is also formed by the crista endocoronoidea which forms a strong posterior border of the clearly marked sulcus endocoronoideus. On the lateral side of the ramus and corpus the linea obliqua ends in a well-developed tuberculum laterale which gives the lower rim of the mandibular body a somewhat angulated appearance.

TABLE 6: Measurements and indices of the mandible.

\begin{tabular}{|c|c|c|}
\hline M.65 & - condylar breadth & 122 \\
\hline M.65(1) & - coronoid breadth & 105 \\
\hline M.66 & - bigonial breadth & 89 \\
\hline M. 67 & - bimental breadth & 42 \\
\hline M. 68 & - length of mandible & 73 \\
\hline M.69 & - symphysis height & 33 \\
\hline M.69(1) & - corpus height (for. mentale) & 33 \\
\hline M.69(2) & - corpus height $\left(\mathrm{M}_{2}\right)$. & 26 \\
\hline M.69(3) & - corpus thickness (for. mentale) & 12 \\
\hline M.70 & — condyloid height & 58 \\
\hline M.70(3) & - incisure depth & 14 \\
\hline M.71 & - ramus breadth (d.37-s.35) & 36 \\
\hline M.79 & - mandibular angle & $58^{\circ}$ \\
\hline 1.63 & - ramus index & 162.11 \\
\hline I.66 & - thickness/height corpus & 36.36 \\
\hline
\end{tabular}



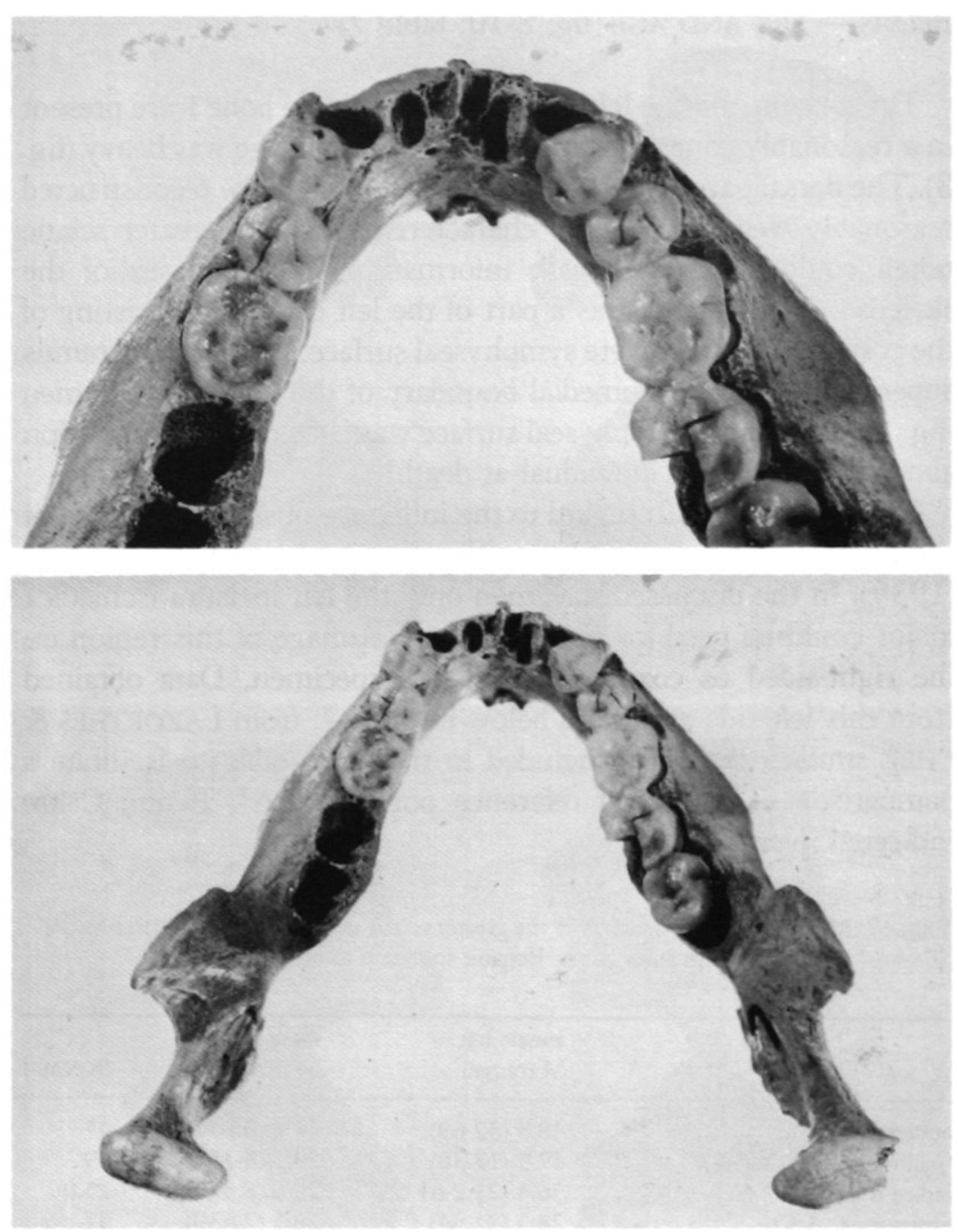

Figure 7a (bottom): Mandible, vertical view.

Figure 7b (top): Mandible, dental region; note the crowding of the (alveoli of) the median incisors. 
PELVIS - SEX AND AGE (fig. 8-10; table 7)

The sacrum and the left and right innominate bone were present in a reasonably complete condition, though damage was heavy (fig. 8 ). The dorsal parts of the innominate bones could be reconstructed reasonably well however, so characteristics of one greater sciatic notch could be used to gain information about the sex of the skeleton. Also present was a part of the left os pubis consisting of the corpus with a complete symphyseal surface, the damaged ramus superior and the anteromedial boundary of the obturator foramen (fig. 10); the intact symphyseal surface was used to add information about the age of the individual at death.

Characteristics with regard to the influence of sex on the form of the greater sciatic notch were studied a.o. by LAZORTHES \& LHEZ (1939). In the discussed specimen only the left incisura ischiadica major could be used for measurements; damage of this region on the right-sided os coxae excluded this specimen. Data obtained from this left side are found below in table 7; from LAZORTHES \& LHEZ similar data were included in the same table to facilitate a comparison. The named reference points $\mathrm{A}, \mathrm{A}$ ', B and $\mathrm{C}$ are indicated in fig. 9.

TABLE 7: Measurements and indices of the greater sciatic notch (from LAZORTHES \& LHEZ) compared with those of the Bonaire specimen from the similar side

\begin{tabular}{llll}
\hline & $\begin{array}{l}\text { female left } \\
\text { M (range) }\end{array}$ & $\begin{array}{l}\text { male left } \\
\text { M (range) }\end{array}$ & BONAIRE \\
\hline ouverture (AB) & $48.8(32-69)$ & $47.4(34-57)$ & 45 \\
'petite ouverture' (AA') & $17.5(12-30)$ & $10.1(3-18)$ & 9 \\
indice d'ouverture (AA'/A'B) & $36.3(21.2-65.6)$ & $20.6(8.3-34)$ & 25.0 \\
profondeur (A'C) & $28.3(21-34)$ & $28.5(22-39)$ & 37 \\
\hline
\end{tabular}



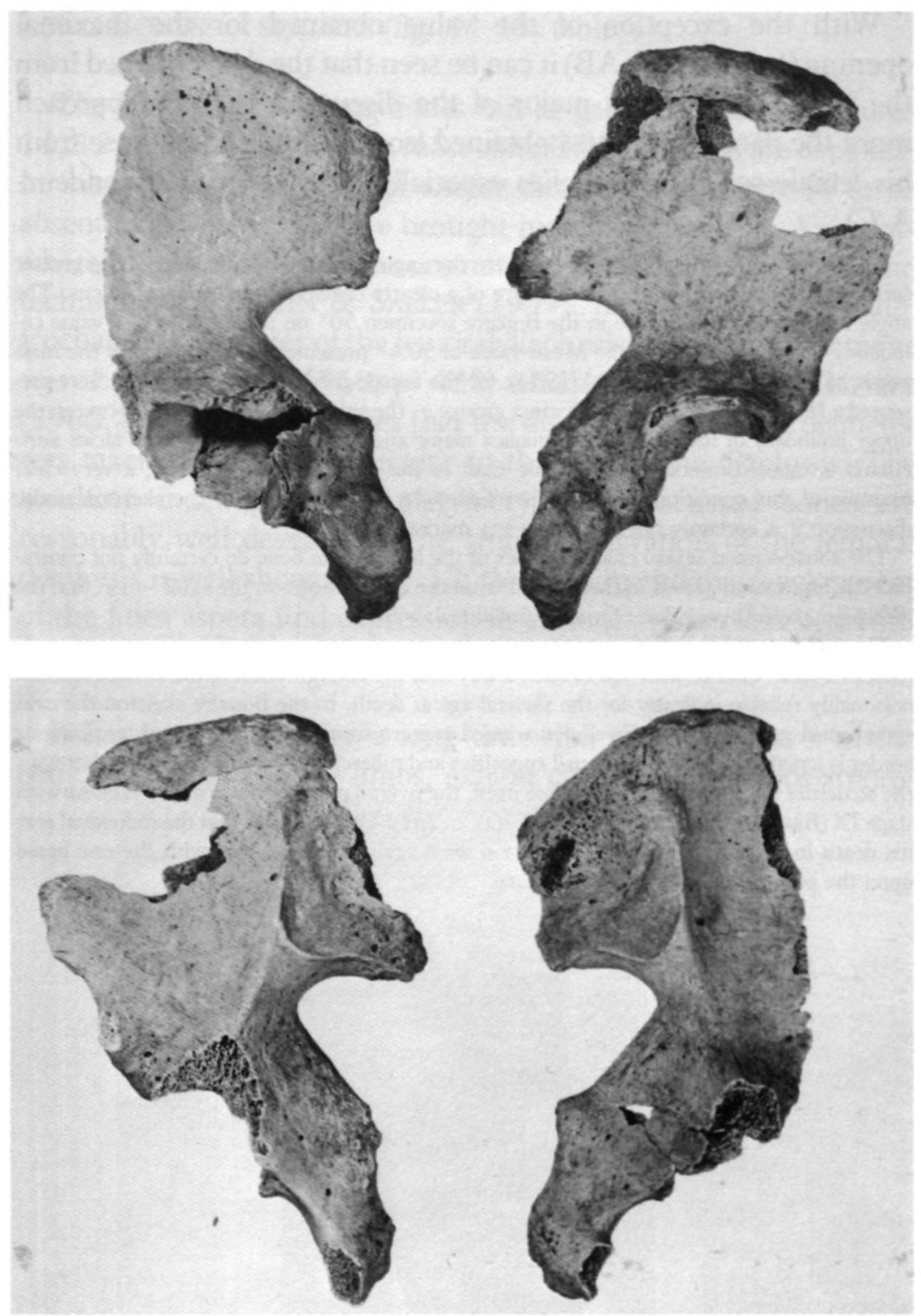

Fig. 8: Left and right innominate bone; inner surface (lower picture) and outer surface upper picture). 
With the exception of the value obtained for the maximal opening ('ouverture'-AB) it can be seen that the data obtained from the incisura ischiadica major of the discussed skeleton approach more the data LAZORTHES obtained from his male than those from his female series; this applies especially to the depth (Profondeur$\left.\mathrm{A}^{\prime} \mathrm{C}\right)$.

Also useful in sexing a given skeleton are the angle made by the tangents of the greater sciatic notch and the presence or absence of a clearly developed preauricular sulcus. The angle mentioned proved to be in the Bonaire specimen $50^{\circ}$ on the left side - a value coinciding nearly exactly with the Mean value of $50.4^{\circ}$ presented for this angle in the male pelvis by HANNA \& WASHBURN (1953); for the female pelvis the mentioned authors presented a Mean value of $74.4^{\circ}$. A distinct groove - the sulcus preauricularis - between the upper boundary of the incisura inschiadica major and the lower border of the facies auricularis is more common in the female than in the male innominate bone; a very clear example of this condition is depicted by GENOVES (1962, fig. 6). In the skeleton under discussion it is certainly not present to any marked extent.

The above-named sexual characteristics of the innominate bone do certainly not contradict the impression gained in this respect from the observations on the skull - i.e. that the discussed skeleton was that of a male individual.

The nodules and elevations present at the free symphyseal surface (fig. 10) present peculiarities which change with age in such a way that the configuration of the surface forms a reasonably reliable indicator for the skeletal age at death. In the Bonaire skeleton the oval symphyseal surface forms a well-demarkated postero-superior border; the antero-inferior border is irregular and presents small rugosities and tubercles of varying size. Together with the structure of the symphyseal surface itself, the overall picture shows much likeness with stage IX (BroOKs 1955, after Olivier 1960, p. 231). This indicates that the individual met his death in his fifth decade; an estimation wich again coïncides well with the one based upon the pattern of cranial suture closure.

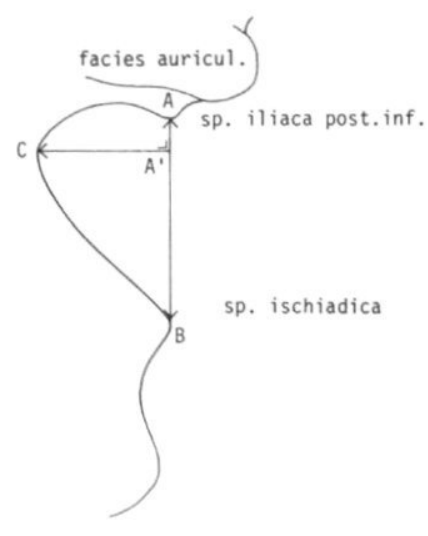

Fig. 9: Location of reference points A, A', B and C in the greater sciatic notch. 
LONG BONES - STATURE (fig. 11-13; table 8)

The features of the long bones can be gathered from the figures 11,12 and 13 on which the most complete specimens are depicted. In many cases the proximal and/or distal epiphysis proved to be absent. The metric data are brought together in table 8. As everywhere in this study the measurements were taken according to the technique of MARTIN \& SALLER (1957). In one case - the subtrochanteric diameter of the femoral diaphysis - the used technique was that of COMAS (1960, p. 425) which is also used by OLIVIER (1960, p. 238). This implies that the discussed transverse diameter was taken simply perpendicular to the axis of the diaphysis. The resulting index points to platymery. The discussed bones are reasonably well developed. The anterior curvation of the femoral diaphysis is well shown in fig. 12; this feature and the development of the linea aspera find expression in an index pilastricus of 114.8 ('pilastre moyen' in the classificaton of OLIVIER, p. 238).

It has been known for a long time that the major parts of the body, the trunk and the limbs, exhibit characteristic ratios among

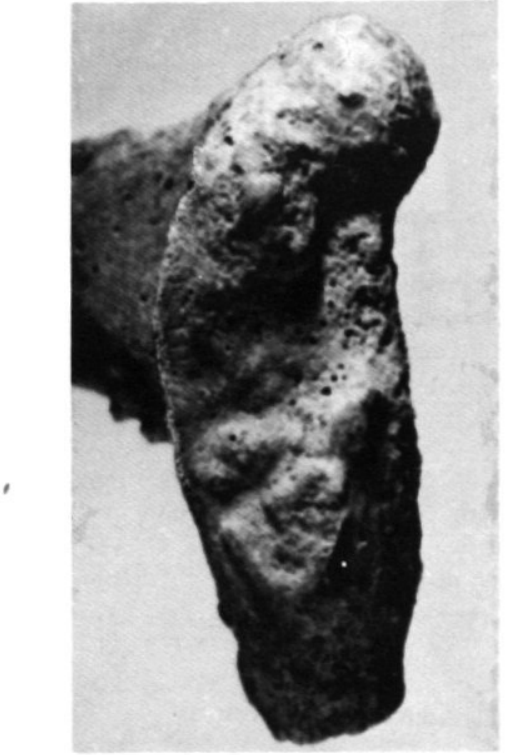

Fig. 10: Symphyseal surface on the left corpus ossis pubis. 
themselves and in comparison to the total height of the individual; proportions which are linked to race, sex and age. This observation has been the ratio underlying the assessment of stature from the size of long bones.

Several tables and formules are in common use for this purpose; among the oldest and best-known are the tables of MANOUVRIER (1892) and the equations of PEARSON (1898) both being based on French material studied by ROLLET (1888). The importance of the determination of stature in the Antillean skeletal material was pointed to previously by ENGELS (1950); the care with which the Bonaire skeleton was collected made an estimation of stature possible as at least some long bones were in such a good state of preser-

TABLE 8: Measurements and indices of pelvis and long bones.

\begin{tabular}{|c|c|c|c|c|}
\hline humerus & right & left & & \\
\hline M.1 - greatest length & - & $315 ?$ & & \\
\hline M.7 - diaphysis minim. circumference & 64 & 64 & & \\
\hline \multirow[t]{3}{*}{ Index lengt/thickness } & - & 20.32 & & \\
\hline & \multicolumn{2}{|c|}{ radius } & \multicolumn{2}{|c|}{ ulna } \\
\hline & right & left & right & left \\
\hline M.1 - greatest length & 252 & - & 276 & - \\
\hline M.2 - physiol. length & 242 & - & 244 & - \\
\hline M.3 - diaphysis minim. circumference & 43 & - & 37 & 37 \\
\hline Index length/thickness & 17.77 & - & 15.16 & - \\
\hline \multicolumn{5}{|l|}{ pelvis - remaining fragments } \\
\hline incisura ischiadica major (fig. 9) & right & left & & \\
\hline 'ouverture' AB (Lazorthes) & $45 ?$ & 45 & & \\
\hline 'profondeur' CA' (Lazorthes) & - & 37 & & \\
\hline 'petite ouverture' AA' (Lazorthes) & - & 9 & & \\
\hline 'indice de l'ouverture' (CA'/AB) & - & 82.22 & & \\
\hline index $\mathrm{AA}^{\prime} / \mathrm{A}^{\prime} \mathrm{B}$ & - & 25.00 & & \\
\hline femur & right & left & & \\
\hline M.1 - greatest length & - & - & & \\
\hline M.2 - physiol. length & $43 ?$ & - & & \\
\hline diaphysis, upper transv. diameter & 33 & - & & \\
\hline M.10 - diaphysis, upper sagittal diameter & 26 & - & & \\
\hline middle transv. diam. & 27 & 27 & & \\
\hline middle sag. diam. & 31 & 31 & & \\
\hline M.21 - epicondylar breadth & - & - & & \\
\hline Index platymericus & 79.8 & - & & \\
\hline Index pilastricus & 114.8 & 114.8 & & \\
\hline
\end{tabular}


vation that they could be used as a starting-point i.e. the right radius and the ulna; from table 8 it can be seen that their measure are:

\begin{tabular}{lcc} 
& radius & ulna \\
\hline greatest length & 252 & 276 \\
physiol. length & 242 & 244
\end{tabular}

As the Amerindians are derived from mongoloid ancestors, it seemed most fit to use for this assessment tables or equations from groups which have affinities in this direction. Choosen were the formulae of STEVENSON (1929) based upon studies on Chinese and formulae and tables of TELKKÄ (1950) derived from Finnish material.
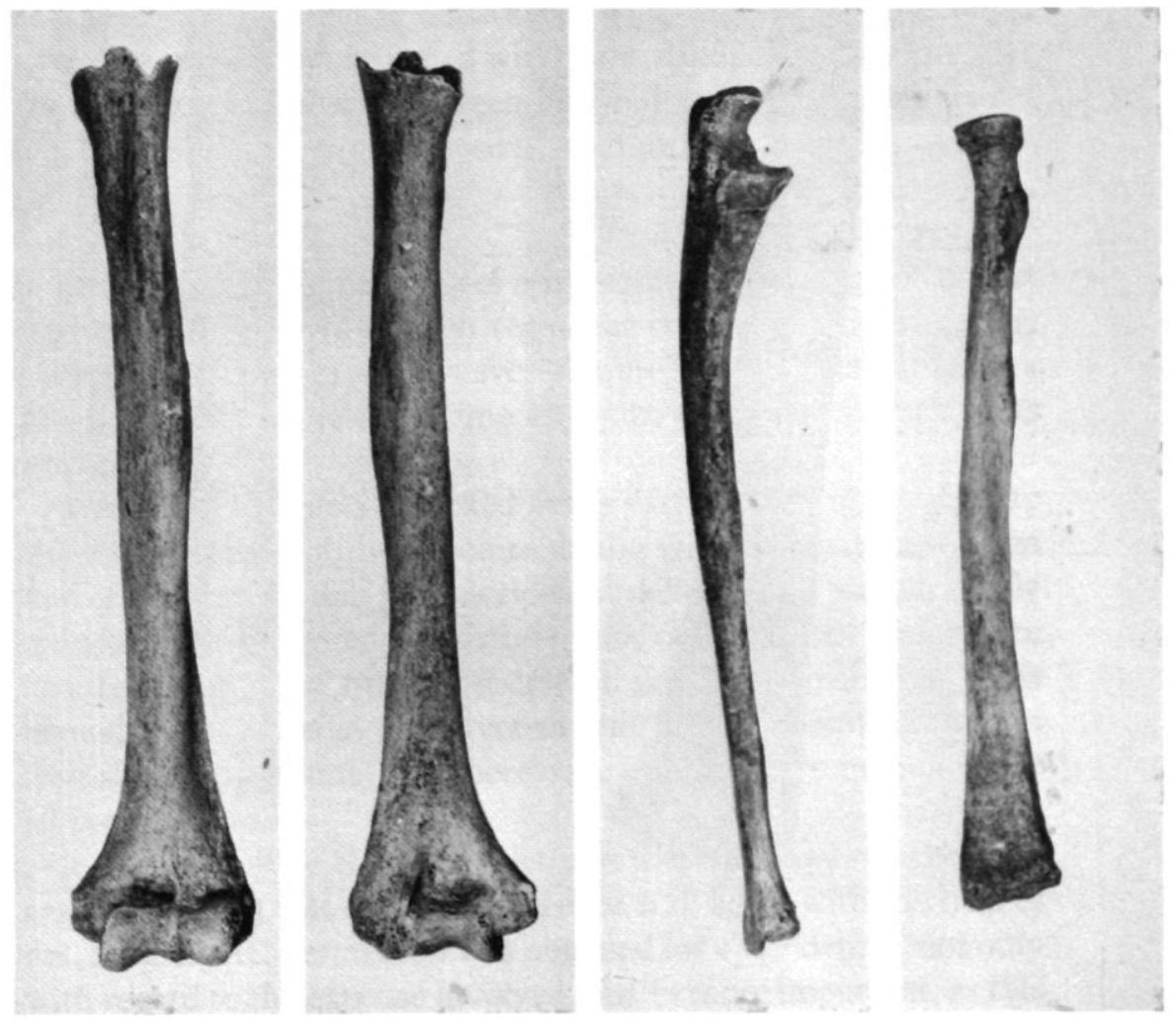

Fig. 11. Damaged left humerus, the intact right radius and ulna. 
250

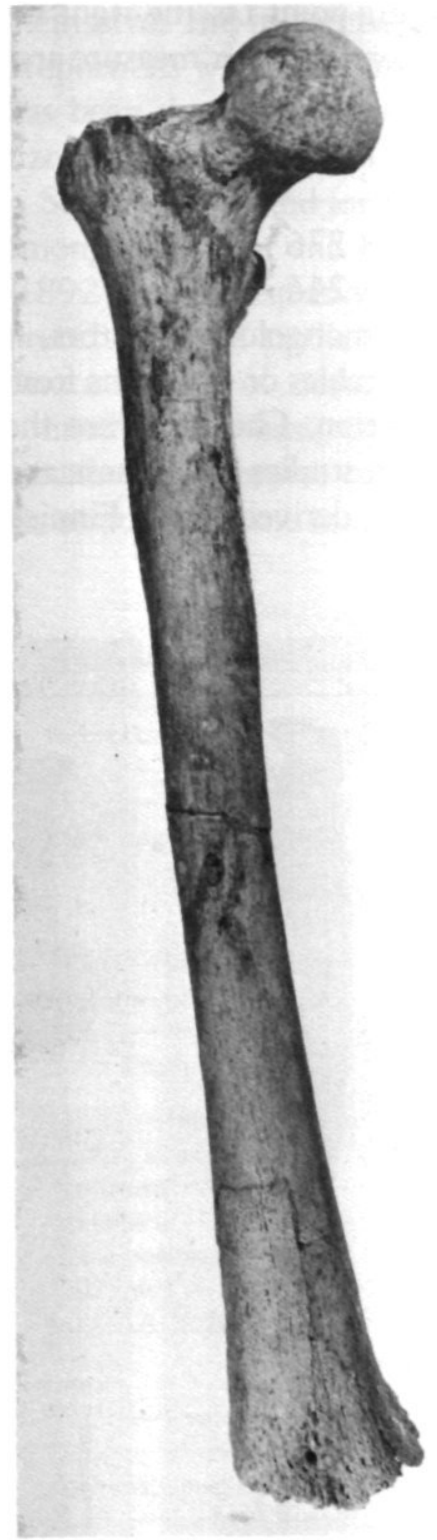

J. TACOMA

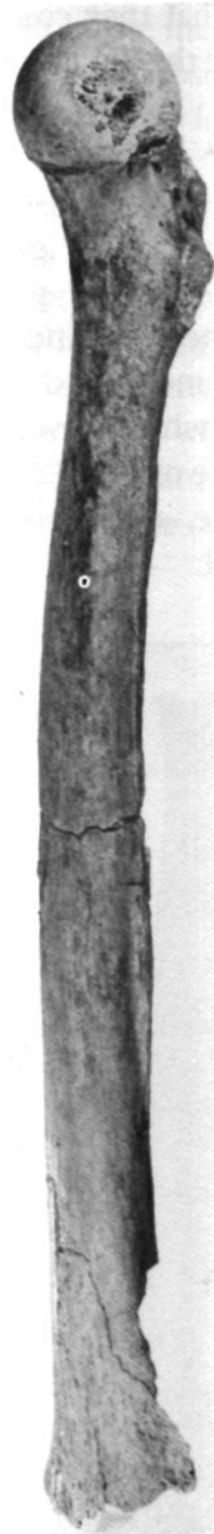

Fig. 12: Damaged right femur. 


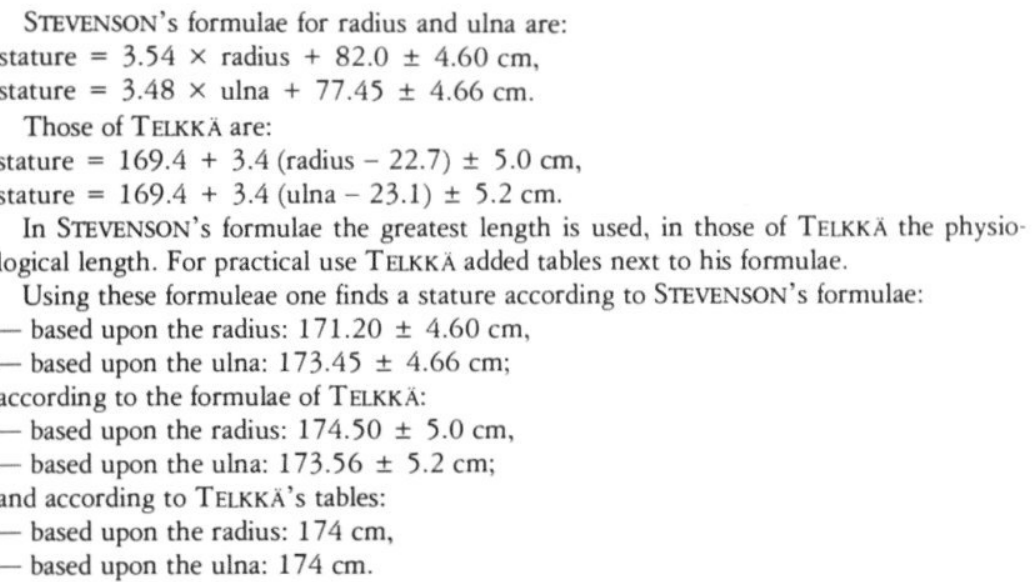

These values coïncide remarkably well, especially those based upon the ulna. It can be stated with some confidence therefore that the body length must have been between at least 170 and somewhat more than $176 \mathrm{~cm}$; possibly even more.

\section{DATING}

Dating skeletal remains gives a possibility to reconstruct at least part of the history of a given region or country. Without dating, every physical type, - however minutely reconstructed from a given skeleton - floats in time and with that, looses much of its importance.

Too often this was overlooked in the past and lack of insight into the requirements of the absolute dating with $\mathrm{C}^{14}$ may have been one of the reasons that from accidental skeletal finds too often only the skull was delivered for a study. Not only age, sex and stature can be determined from post-cranial skeletal remains; it yields enough bony material to deliver the minimum amount of (in this case about 250 grams) bone necessary for the determination of the $\mathrm{C}^{14}$ content.

In the case of the Bonaire skeleton it was else however; the postcranial skeleton was amply represented and, again with the help of drs. L.H. DAAL, permission was obtained for a $\mathrm{C}^{14}$ dating, not only with regard to the expense involved, but - more important, as this skeletal find was the only one hitherto reported from Bonaire - 

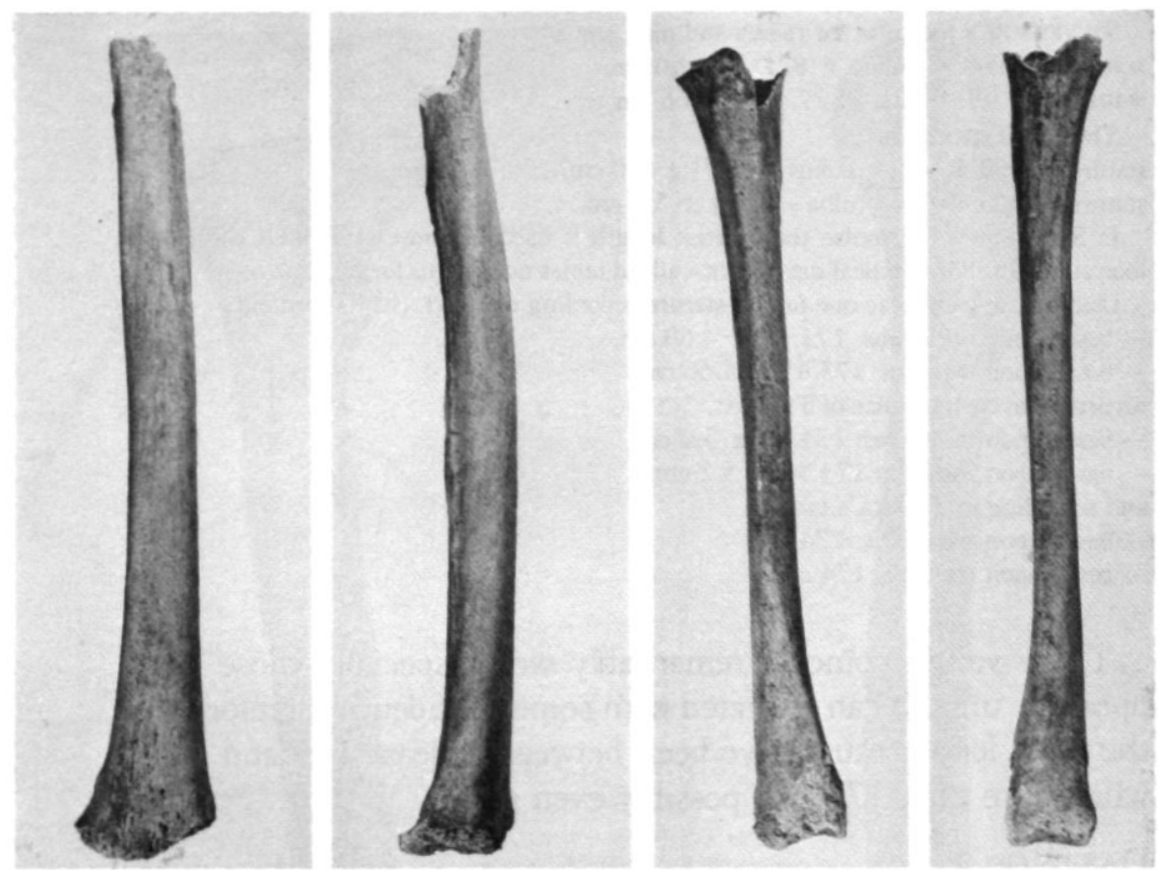

Fig. 13: Damaged left femur (sacrified for $\mathrm{C}^{14}$ dating) and damaged right tibia.

with regard to the amount of skeletal material which had to be sacrified. The left femur was used for this purpose - it provided the sufficient minimum amount of bone material and it was the least useful specimen for an anthropological investigation as the proximal as well as the distal epiphysis were broken away and missing. Dating was carried out in the Institute of General Physics of the State University of Groningen; the absolute age of the skeleton was found to be 760 years \pm 25 years.

\section{Discussion}

The Bonaire skeleton yielded data on the skull - craniometric measurements and their indices, non-metric characteristics, indications of the sex of the individual and its age at death - and data of the post-cranial skeleton. The impressions regarding the sex and age of the individual gathered from the skull were confirmed by the characteristics of the pelvic remains. The intact radius and ulna 
made a calculation of the stature possible and the heavily damaged left femur provided enough material to make a $\mathrm{C}^{14}$ dating possible.

From these data, those on craniometry, the stature and the dating allow a discussion.

Known cranial series in South-America enabled STEWART \& NEWMAN (1963) to discover a geographical segregation of some of the recorded measurements and indies. Those which showed this segregation and which could be used for comparison with similar data from the Bonaire skeleton are mentioned below; the data themself can be found in the Handbook of South-American Indians (vol. VI) were they are tabulated in a most convenient, clearly structured way.

A geographical segregation proved to exist in the cranial length, the cranial breadth and height, the cranial module, the upper facial height and maximum facial breadth, the nasal height and breadth and - as can be expected - in some of their indices; the disadvantage of the latter quotients is that they tend to obscure the original data. It has to be kept in mind that data on some of the series mentioned go back to the beginning of present-day techniques. Also that artificial cranial deformation affects length, breadth and height of a skull. If the sequelae of artificial deformation are clear, the specimen can be excluded from a studied series. Problems threaten if a deformation is so slight that its sequalae - a.o. frontal flattening - escape the investigators attention or only causes an inkling of doubt; if this is mentioned the reader is warned - if not, an entity can come to existence which may be more brachycephalic than it should be. With this in mind the warning of STEWART \& NEwMAN (1963, p. 19) can be understood easily: 'Pervading all of the records, therefore, is a certain unreliability, which no amount of statistical analysis can evaluate or overcome'. We have, however, nothing else.

\footnotetext{
It seemed most rational to compare the data of the Bonaire skull with those of the known Venezuelan series.

In the continent the cranial length was found to be smallest in the west and north-west and greatest in the east and south-east. If the cranial length of the Bonaire skull is compared with those recorded from Venezuelan series it is found that it fits into the lower reaches of the recorded ranges.

The cranial breadth fits into the higher reaches of the mentioned ranges and the basionbregma height fits into them without difficulty; the cranial module of the discussed
} 
specimen also coïncides well with the geographical distribution on the continent, this applies also to the mean height index.

No Venezuelan records of the upper facial height were mentioned in the tables used for comparison; data on the maximum facial breadth are present however - the estimated value of $141 \mathrm{~mm}$ in the Bonaire skull certainly lies in the upper reaches of the ranges recorded. The upper facial index was mentioned in a small series $(n=4)$ from a location designated as Colombia/Venezuela. The corresponding upper facial index of the Bonaire specimen lies above the given Mean but still falls within the range.

Nasal height and breadth also proved to show a distinct geographical segregation. If the Venezuelan data are compared with those from the Bonaire facial skeleton it is found that the latter's nasal height falls into the upper reaches of most of the recorded ranges; the reverse is found in the case of the nasal breadth.

In comparison with the recorded Venezuelan groups the above may be summarized by stating that the Bonaire skull is more brachycephalic, has a slightly broader facial skeleton and a narrower nose.

The section on the skeletal remains from the South-American continent mentioned above was limited to craniometric data; measurements of long bones were absent, so from these groups no stature could be calculated with any of the given methods used for the Bonaire skeleton. The living however provided data, not only on the cephalic index, but also on the stature; they were summarized by STEGGERDA (1963). According to the map he presents in the above-mentioned Handbook (vol. VI, p. 59) it can be seen that 'small statures, below $160 \mathrm{~cm}$, are found in the north-west and continue south-eastward to more or less the center of the Continent, with a few scattered groups in southern Paraguay and Brasil. Those between 160 and $165 \mathrm{~cm}$ occupy nearly the same area, but continue farther south along the western part of the Continent, far into Chile. The next taller group, of 165 to $170 \mathrm{~cm}$ occupies a long narrow strip reaching from northern Brasil to southern Argentina. Still larger Indians, averaging above $170 \mathrm{~cm}$, are found in the southern part of the South America and at its southermost tip... A small group of very tall Indians, the Bororo, occupies a small region in central Brazil'.

The Bonaire skeleton belonged to an Indian who clearly exceeded the stature expected on the base of data from the nearby continent.

Especially with regard to this stature, the historical study of ENGELS (1970) and the fact that the $\mathrm{C}^{14}$ dating yielded an age which placed the skeleton a few hundred years prior to the border of the prae- and post-Columbian era, are of importance. The more than average stature of Indians inhabiting the Lesser Antilles mentioned, according to ENGELS, a.o. by VESPUCCI, was very much disputed. VESPUCCI's statement is more or less corroborated by this skeleton. The dating itself places the skeleton in period IV (CRUXENT \& Rouse 1958, after Du RY 1960, p. 87) of Venezuelan archaeology; for the bearing of this chronology to the archaeology of the Lesser Antilles the reader is referred to the papers of Du RY (1960) and VAN HEEKEREN (1960). 
It seems really worthwhile, in view of the abovementioned facts to continue on the road on which this study is no more than a first step; i.e. to excavate skeletal remains as careful as possible so that craniological observations can be made - not only those - but also data on intact long bones from which the stature can be assessed. Enough material should be gathered so that a $\mathrm{C}^{14}$ dating is possible. In this way, not only morphological data are added to our knowledge - to the many existing already which can be used for comparative purposes - but far more important: these data will find a place in the time and so eventually a chronological sequence can be made. Up till now, this latter is sadly lacking.

\section{SAMENVATTING}

Het besproken skelet werd gevonden tijdens bouwwerkzaamheden; de fragmenten van de schedel en van het post-craniële skelet konden verzameld worden en werden voor een studie naar de auteur gezonden. Na reconstructie bleek het voor zover auteur bekend, het meest complete skelet te zijn dat uit de Antillen ter bestudering werd aangeboden.

De mogelijk gemaakte $\mathrm{C}^{14}$ datering - uniek voor skeletmateriaal uit dit gebied - wees op een ouderdom van 760 jaar \pm 25 jaar; de onafhankelijk hiervan gemaakte ras-diagnose 'indiaans' werd hierdoor bevestigd. Aan de hand van karakteristieken van de schedel en van de aanwezige fragmenten van het bekken werd de geslachtsdiagnose op mannelijk gesteld en de bereikte leeftijd werd geschat op $40-50$ jaar.

De breedte/lengte verhouding (index) van 86.55 wijst op een ronde schedel, die hoog is in verhouding tot de lengte (hoogte/lengte index 74.85) en laag in verhouding tot de breedte (hoogte/breedte index 86.49). De bovengezichtsindex van 54.60 wijst op een gezicht met een gemiddelde breedte; de verticale afmeting van de oogkassen is tamelijk groot ten opzichte van de horizontale (orbitale index 85.71); de neus bleek tamelijk smal. Er waren geen duidelijke aanwijzingen voor een kunstmatige deformatie van de schedel.

Het intact zijn van enkele lange pijpbeenderen - in dit geval de rechter ellepijp en het rechter spaakbeen - maakte een berekening van de lichaamslengte mogelijk. De uitkomst - ongeveer $175 \mathrm{~cm}-$ 
was verrassend als men deze vergelijkt met verwachtingen gebaseerd op lichaamslengten van levende indianen op het nabij gelegen vasteland. Minder verrassend als men de historische gegevens in gedachten neemt.

In vergelijking met gegevens ontleend aan osteometrische studies in het verleden van groepen uit Venezuela kan gesteld worden dat het skelet uit Bonaire wat meer brachycraan is, een smallere neus heeft en een wat breder gezichtsskelet. De lichaamslengte overtreft duidelijk die van indianen in het noord-westelijke deel van het Zuid-Amerikaanse vasteland.

\section{RESUMEN}

El esqueleto que se estudia fue hallado durante unas obras de construcción; los fragmentos del cráneo y del esqueleto poscraneal pudieron recogerse y fueron enviados al autor. Realizada la reconstrucción se evidenció que se trata de un esqueleto extremamente completo, a juicio del autor, el más completo procedente de las Antillas que hasta ahora fue sometido a estudio.

La determinación de la edad por medio de $\mathrm{C}^{14}$ - caso único para material esquelético de esta región - dio como edad: 760 años \pm 25 años; la diagnosis racial de 'indio' realizada independientemente, fue confirmada por ello. A raiz de caracteristicas del cráneo y de los fragmentos de la pelvis presentes, fue determinada que se trata de un ser masculino, estimándose la edad alcanzada en vida entre los 40 y los 50 años.

La proporción anchura/longitud (indice) de 86.55 implica un cráneo redondo, alto en relación con su longitud (indice altura/ longitud 74.85) y bajo en relación con la anchura (indice altura/anchura 86.49). El indice suprafacial de 54.60 indica una cara de una anchura media, la dimensión vertical de los órbitas es bastante grande respecto de la horizontal (indice orbital 85.71); la nariz resultó bastante estrecha. No hubo indicios claros de deformación artificial del cráneo.

El haber permanecido intactas algunas canillas largas - en este caso el cúbito derecho y el radio derecho - hizo posible el cómputo de la longitud del esqueleto. El resultado - aproximadamente 175 - fue sorprendente si se compara con las expectaciones basadas en longitudes del cuerpo de indios vivos en la cercana tierra firme. 
Menos sorprendente, si se consideran los datos históricos.

En comparación con datos tomados en el pasado de estudios osteométricos de grupos procedentes de Venezuela, se puede afirmar que el esqueleto de Bonaire es algo más braquicéfalo, que tiene la nariz más estrecha y el esqueleto facial más ancho. La longitud excede claramente la de los indios de la región noroeste del continente suramericano.

\section{RERERENCES}

BrooKs, S.T., 1955. Skeletal age at death; the reliability of cranial and pubic age indicators. Am. J. Phys. Anthrop. (n.s.) 13: $567-579$ (after Olivier).

Comas, J., 1960. Manual of physical antbropology. Charles C. Thomas, Springfield, Illinois.

CRUXENT, J.M. \& RouSE, I., 1958. An archaeological chronology of Venezuela, I. Social Science Monogr. 6, Pan-Amer. Union, Washington - 1961. Arqueologia chronológica de Venezuela I, 320 pp.

DU RY, C.J., 1960. Notes on the pottery of Aruba, Curaçao and Bonaire. Studies on the archaeology of the Netherlands Antilles: I. Nieuwe West-Indische Gids 40:81-102. - Also in Uitg. Natuurwet. Werkgroep Ned. Ant. 10.

Engels, C. \& Bork-FeltKamp, A.J. van, 1970. Opgravingen te Malmok op Aruba. De kwestie 'Gigan'. Het Curaçaosch Museum, 44 pp. (Measurements of skull by VAN BORKFELTKAMP, p. 23-27).

GeNOveS, T. Santiago, 1960. Introducción al diagnóstico de la edad y del sexo en restos óseos prehistóricos. Universidad nacional autonoma de México.

HANNA, R.E. \& WASHBURN, S.L., 1953. Determination of the sex of skeletons as illustrated by a study of the Eskimo pelvis. Human Biology 25: 21-27.

HeEkEREN, H.R. vaN, 1960. A survey of the non-ceramic artifacs of Aruba, Curaçao and Bonaire. Studies on the archeology of the Netherlands Antilles II. Nieuwe West-Indische Gids 40: 103-120. - Also in Uitg. Natuurwet. Werkgroep Ned. Ant. 10.

HeEkeren, H.R. van, 1963. Prehistorical research on the islands of Curaçao, Aruba and Bonaire in 1960. Studies on the archeology of the Netherlands Antilles: III. Nieuwe WestIndische Gids 43: 1-24. - Also in Uitg. Natuurwet. Werkgroep N.A. 15.

KoEZE, G.A., 1904. Schädel von Curaçao und Aruba. Beiträge zur Anthropologie, Ethnologie und Archeologie Niederl. Westindiens. Mitt. Niederl. Reichsmus. Völkerk. Veröff. (2) 9: $18-22$. 
LAZORTHES, G. \& LHEZ, A., 1939. La grande échancrure sciatique. Étude de sa morphologie et de ses charactères sexuels. Arch. Anat. Hist. et Embr.: 143-169.

MANOUVRier, L., 1892. La détermination de la taille d'après les grands os des membres. Mém. Soc. Anthrop. Paris 4: 347-402 (after Olivier).

Martin, R. \& SalleR, K., 1957, 1959. Lebrbuch der Anthropologie. I \& II. Gustav Fischer, Stuttgart.

PEARSON, K. 1899. On the reconstruction of the stature of prehistoric races. Mathem. contribution to the theory of evolution V. Philosoph. Trans. Roy. Soc. (A) 192: 169-244 (after OLIVIER).

OLIvIER, G., 1960. Pratique anthropologique. Vigot Frères, Paris.

STEVENSON, P.H. 1929. On racial differences in stature long bones regression formulae for the Chinese. Biometrika 21: 303-321.

Steggerda, M., 1963. Anthropometry of South American Indians. Handbook of South American Indians 6: 57-70. Cooper Square Publishers Inc., New York.

Stewart, T.D. \& Newman, M.T., 1963. Anthropometry of South American Indian skeletal remains. Handbook of South American Indians 6: 19-43.

TACOMA, J., 1959. Indian skeletal remains from Aruba. Studies o the physical anthropology of the Netherlands Antilles: II. West-Indische Gids 39: 95-112. - Also in Uitg. Natuurwet. Werkgroep N.A. 9.

TACOMA, J., 1964. Kunstmatige schedeldeformatie in Aruba (Artificial skull deformation in Aruba). Studies on the physical anthropology of the Netherlands Antilles: III. Nieuwe West-Indische Gids 43: 211-222.

- Taсома, J., 1965. Craniology of Aruban Indians. In Homenaje a Juan Comas en su 65 aniversario II: 367-376 México.

Telkkä, A., 1950. On the prediction of human stature from the long bones. Acta Anatomica 9: 103-117.

WagenaAr Hummelinck, P., 1959. Indiaanse skeletvondsten op Aruba en Curaçao (Indian skeletal discoveries in Aruba and Curaçao). Studies on the physical anthropology of the Netherlands Antilles: I. West-Indische Gids 39: 77-94. - Also in Uitg. Natuurwet. Werkgroep N.A. 9 .

Dr. J. TACOMA,

Anatomisch Lab. der Rijksuniversiteit

- Janskerkhof 3, Utrecht. 